\title{
Political Street Stickers in Resistance to Biopower in Poland: The Case of Krakow During the 2020 Polish Presidential Election Campaign
}

\author{
MICHAEL COLE
}

\begin{abstract}
Though largely ignored by scholars of political participation, stickers are an increasingly common means of expressing socio-cultural identities and a staple of contemporary protest movements. In Poland, the "LGBT-Free Zone" stickers sold with the newspaper Gazeta Polska in 2019 provided a clear demonstration of ruling party Law and Justice's (PiS) hegemonic and exclusionary bioconservative discourse. A year later, during the 2020 presidential elections, as issues related to LGBT+ rights became a key battleground revealing socio-political divisions in the country, a series of proLGBT+ stickers appeared in Krakow. This paper first evaluates the combination of linguistic and visual elements that makes political stickers a unique genre of expression. Multimodal discourse analysis of the pro-LGBT+ stickers posted in Krakow subsequently reveals an alternative conceptualization of "Polishness" that includes the $L G B T+$ community rather than excluding it on biopolitical grounds.
\end{abstract}

Keywords: Poland, LGBT activism, Law and Justice, visual politics, biopolitics 


\section{Michael Cole}

Today, stickers are "always visible, yet rarely seen, read and understood" in towns and cities across Europe. While many are produced and posted for commercial purposes,${ }^{2}$ stickers have become more commonly used to express socio-cultural and political identities and reinforce feelings of group membership. ${ }^{3}$ Their small size and duplicability, as well as the relative ease of maintaining anonymity and thus evading legal repercussions when posting them, means they have become "the main medium, therefore one of the main techniques of street art" 4 and a "staple of contemporary repertoires of protest." 5

Despite this, stickers remain largely ignored by scholars of political participation and protest, ${ }^{6}$ even though their prevalence in a wide range of contexts as a means of displaying allegiance or opposition to socio-political causes makes them an important subject for researchers of visual politics. Therefore, this paper first evaluates the combination of linguistic and visual elements that makes political stickers a unique genre of expression ${ }^{7}$ and communication. ${ }^{8}$ I argue that the socio-cultural context ${ }^{9}$ and spatio-temporal positioning of stickers are not only crucial factors in fully understanding the meanings they convey, ${ }^{10}$ but also provide important insights regarding the content and nature of counter-hegemonic discourses present in these societies.

Having established a broader framework for analyzing political stickers, this paper takes the 2020 Polish presidential election campaign as a case study. During this period, LGBT + rights issues emerged as a key nodal point revealing socio-political divisions in the country ${ }^{11}$ after a weekly national newspaper distributed stickers featuring homophobic slogans consistent with the illiberal ideological values promoted by ruling party Law and Justice (PiS). ${ }^{12}$ What follows is a multimodal discourse analysis of pro-LGBT+ stickers posted in Krakow as an act of resistance against PiS and incumbent president Andrzej Duda, whose biopolitical agenda discursively excluded the LGBT+ community from the Polish nation. ${ }^{13}$

\section{The Political Street Sticker: A Unique Genre of Political Expression}

Hiding in plain sight, even more so than such street art forms as graffiti, stencils, and murals, stickers have since the 1970 s become commonly used to express socio-

1 Mitja Velikonja, Post-Socialist Political Graffiti in the Balkans and Central Europe, (London: Routledge, 2019), xii.

2 Orla Vigsø, "Extremist Stickers: Epideictic rhetoric, political marketing, and tribal demarcation," Journal of Visual Literacy 29, no. 1 (2010): 28-46, 30, https://doi.org/10.1080/23796529.2010.11674672.

3 Gertrud Reershemius, "Lamppost Networks: Stickers as a genre in urban semiotic landscapes," Social semiotics 29, no. 5 (2019): 623, https://doi.org/10.1080/10350330.2018.1504652.

4 Velikonja, Post-Socialist Political Graffiti, 143.

5 Hannah Awcock, "Stickin' It to the Man: The geographies of protest stickers," Area 53, no. 3 (2021): 2, https://doi.org/10.1111/area.12720.

6 Ibid., 7.

7 Vigsø, “Extremist Stickers,” 30.

8 Reershemius, "Lamppost Networks," 623.

9 Linda-Renée Bloch, "Mobile Discourse: Political Bumper Stickers as a Communication Event in Israel," Journal of Communication 50, no. 2 (2000): 48-76, 65, https://doi.org/10.1111/j.1460-2466.2000.tbo2841.x. 10 Velikonja, Post-Socialist Political Graffiti, 7.

11 Philippe Theise, "LGBT Rights at heart of Poland presidential-election fight," France 24, July 11, 2020, https://www.france24.com/en/20200711-lgbt-rights-at-heart-of-poland-presidential-election-fight.

12 Piotr Żuk, Przemysław Pluciński, and Paweł Żuk, "The Dialectic of Neoliberal Exploitation and CulturalSexual Exclusion: From Special Economic Zones to LGBT-Free Zones in Poland," Antipode (2021): 11, https:// doi.org/10.1111/anti.12721.

13 Bartosz Płotka, "Biopolitics, Ideology, and Citizenship," Journal of Contemporary Central and Eastern Europe 26, no. 2-3 (2018): 131-146, https://doi.org/10.1080/25739638.2018.1526488; Alexandra Yatsyk, "Biopolitical Conservatism in Europe and Beyond: The Cases of Identity-Making Projects in Poland and Russia," Journal of Contemporary European Studies 27, no. 4 (2019): 463-478, https://doi.org/10.1080/1478 2804.2019.1651699. 
cultural and political identities and reinforce feelings of group membership. ${ }^{14}$ Combining linguistic and visual elements, stickers also represent a unique genre of political and subcultural expression ${ }^{15}$ and communication ${ }^{16}$ that can only be fully understood alongside knowledge of the socio-cultural context ${ }^{17}$ and spatio-temporal positioning in which they appear. ${ }^{18}$

Despite being widespread, ${ }^{19}$ political street stickers have thus far received scant academic attention as a genre in their own right. Notable previous studies include Vigsø's analysis of extremist stickers in Sweden; Reershemius' examination of "lamppost networks" as a form of urban communication in Birmingham, England; and Velikonja's case studies from the Balkans and Central Europe, where political and football fan stickers are posted alongside graffiti and other forms of political street art. ${ }^{20}$ Where Vigsø's study noted the increasing number of stickers containing political messages, Reershemius observed that the majority of political street stickers in his research presented radical views, both of the left- and right-wing variety. ${ }^{21}$ Both these points are supported by Velikonja's work, which also highlights the importance of political street stickers within the wider ecosystems of street art and urban political communication. ${ }^{22}$ Building on the contributions made by these prior works, this study first aims to develop a framework for multimodal analysis that treats stickers as a unique form of political expression, independent of other street art mediums. The first step in this process is to define political street stickers in a way that accounts for their unique physical, spatio-temporal, and content-related features.

In physical terms, stickers are usually small pieces of paper or self-adhesive vinyl that contain images, texts or a combination of the two. ${ }^{23}$ Unlike other street art forms, such as stencils, murals or graffiti, stickers are usually mass-produced in advance of posting, ${ }^{24}$ though they may also be handmade. ${ }^{25}$ Their size and replicability allows for quicker distribution over a wider area than is possible with most other forms of street art. ${ }^{26}$ Street stickers are those posted in public spaces, including on walls, lampposts, fences, and any other surfaces to which their adhesive side may stick. ${ }^{27}$ Similar to other forms of "self-authorized" street art, ${ }^{28}$ the act of posting stickers in public space may be considered political in itself, as it is in most instance illegal, ${ }^{29}$ particularly if the location chosen holds political significance (for example, if it is a government or religious building)..$^{30}$

\footnotetext{
14 Reershemius, "Lamppost Networks," 623.

15 Vigsø, "Extremist Stickers," 30.

16 Reershemius, "Lamppost Networks," 623.

17 Bloch, "Mobile Discourse," 65.

18 Velikonja, Post-Socialist Political Graffiti, 7.

19 Vigsø, "Extremist Stickers," 29.

20 Vigsø, "Extremist Stickers”; Reershemius, "Lamppost Networks”; Velikonja, Post-Socialist Political Graffiti.

21 Vigsø, “Extremist Stickers," 29; Reershemius, "Lamppost Networks," 633-634.

22 Velikonja, Post-Socialist Political Graffiti.

23 Reershemius, "Lamppost Networks," 624; Vigsø, “Extremist Stickers," 29.

24 Velikonja, Post-Socialist Political Graffiti, 143.

25 Reershemius, "Lamppost Networks," 624.

26 Velikonja, Post-Socialist Political Graffiti, 143; Carmen Cowick, "Preserving Street Art: Uncovering the Challenges and Obstacles," Art Documentation: Journal of the Art Libraries Society of North America 34, no. 1 (2015): 29-44, 31.

27 Velikonja, Post-Socialist Political Graffiti, 8; Vigsø, “Extremist Stickers,” 31.

28 Ulrich Blanché, "Street Art and Related Terms-Discussion and Working Definition," Street Art and Urban Creativity Scientific Journal 1, no. 2 (2015): 32-39, 34, https://doi.org/10.25765/sauc.v1i1.14.

29 Reershemius, “Lamppost Networks,” 630; Velikonja, Post-Socialist Political Graffiti, 158. 30 Velikonja, Post-Socialist Political Graffiti, 18.
} 


\section{Michael Cole}

The linguistic and pictorial content of street stickers varies considerably, ${ }^{31}$ ranging from overtly political or commercial to purely aesthetic, depending on the aims and tastes of the creators. ${ }^{32}$ This paper argues that it is the nature of this content that determines whether individual street stickers are classified as political or not. Velikonja highlights the importance of location to the creation of meaning behind works of street art, including political stickers. ${ }^{33}$ However, while this may be true for strategically placed works of the kind practiced by stencil artist Banksy, ${ }^{34}$ stickers' ease of replicability and appearance in multiple sites at any given time reduces the importance of micro-location in attributing meaning. The posting of an individual sticker in a politically significant location is generally unlikely to evoke the publicity and strength of reaction, both positive and negative, of a strategically placed mural or graffiti. ${ }^{35}$ Instead, it seems to be the frequency of stickers' appearance in the public space, particularly if there is an element of mystery in the messages or content they display, that increases their impact, especially should they attract media attention..$^{6}$ In this respect, this paper argues that the linguistic and visual messages street stickers carry are the predominant factors in determining their classification as political.

While this accounts for the "political" aspect of the concept, it is also necessary to differentiate political street stickers from another related, yet separate, medium of political expression: political bumper stickers. Having received greater attention in the literature due to their popularity and prominence in both the United States and Israel, ${ }^{37}$ bumper stickers are commonly placed on vehicles by their owners and are thus widely visible as they move around cities. $3^{8}$ Though not all bumper stickers contain political messages, ${ }^{39}$ those that do range from the endorsement of favored electoral candidates, ${ }^{40}$ to expressions of protest, to responses to perceived political crises or social tension. ${ }^{41}$ While the content of political bumper stickers may, in some cases, resemble or mirror that of political street stickers, it is the posting of the latter on public ground, as opposed to private property (usually a vehicle) that represents the key distinction between the two mediums. By appearing on a vehicle with an identifiable owner, bumper stickers directly denote an identifiable individual's political or social identity or affiliation..$^{42}$ In contrast, political street stickers are usually posted anonymously, removing this immediate connection between the messages they display and the individuals to whom those views belong. ${ }^{43}$

Their placement on public ground-rather than on privately owned property at the owner's behest or with their consent-highlights a further defining feature of political street stickers, namely their illegality or unauthorized nature. ${ }^{44}$ Like most other

31 Reershemius, "Lamppost Networks," 624.

32 Vigsø, "Extremist Stickers," 29.

33 Velikonja, Post-Socialist Political Graffiti, 39.

34 Alison Young, "Negotiated Consent or Zero Tolerance? Responding to Graffiti and Street Art in Melbourne," City 14, no. 1-2 (2010), 99-114, 110, https://doi.org/10.1080/13604810903525215.

35 Ibid., 110.

36 Francesco Screti, "Counter-Revolutionary Art: OBEY and the Manufacturing of Dissent," Critical Discourse Studies 14, no. 4 (2017): 362-384, 366, https://doi.org/10.1080/17405904.2017.1284138.

37 James W. Endersby, "Tailgate Partisanship: Political and Social Expression Through Bumper Stickers,” The Social Science Journal 33, no. 3 (1996): 307-319, 308, https://doi.org/10.1016/So362-3319(96)90026-9; Bloch, "Mobile Discourse," 50.

38 Bloch, "Mobile Discourse."

39 Ibid., 51.

40 Endersby, "Tailgate Partisanship," 311.

41 Bloch, "Mobile Discourse," 53.

42 Endersby, "Tailgate Partisanship," 308; Charles E. Case, "Bumper Stickers and Car Signs Ideology and Identity," Journal of Popular Culture 26 (1992): 107-119, 118.

43 Vigsø, "Extremist Stickers," 31.

44 Reershemius, “Lamppost Networks," 625. 
forms of street art and graffiti, street stickers are usually "self-authorized," ${ }^{45}$ fostering a strong association with "urban subcultures and transgressive discourse." 46 As this suggests, the differences between political street stickers and political bumper stickers not only relate to their locations, but also extend to their content. Whereas bumper stickers in both the US and Israeli contexts frequently depict or name political figures ${ }^{47}$ political street stickers generally avoid this, tending instead to reference organizations or movements. In this respect, political stickers are not entirely anonymous, but often connected to wider political ideas and movements denoted by the inclusion of familiar and identifiable organizational symbols, images, and slogans..$^{48}$

This tendency to reference organizations rather than individuals appears to contribute significantly to the types of views expressed on political street stickers, further distinguishing them from political bumper stickers. In common with other street art forms, political street stickers generally present the non-hegemonic discourses ${ }^{49}$ of political actors from "outside of traditional party politics," ${ }^{0}$ with Vigsø and Reershemius both observing that their content is often extreme or radical. ${ }^{11}$ In some cases, street stickers may be one of the only means available for non-traditional political actors to express their views, ${ }^{52}$ particularly in contexts where access to traditional forms of communication is limited or denied..$^{53}$ Thus, in addition to providing a medium for non-hegemonic actors to express their views on political issues, at a more fundamental level, the physical act of marking or "tagging" a public space with political street stickers is also a way of demonstrating that marginalized groups, organizations or ideas exist in a society where they lack other forms of visibility. .54

While street stickers may provide a medium for those who would otherwise be peripheral or excluded to enter political and social debate, 55 the messages they carry are not usually presented in ways inviting discussion..$^{56}$ The language used to accompany images on political street stickers tends to be declarative or rhetorical, directly stating or alluding to the viewpoint of those who produce them in the form of slogans rather than nuanced arguments. ${ }^{57}$ It is thus beneficial to draw on Philipps ${ }^{38}$ distinction between the street art of "resistance" and that of "protest," where "resistance" is a predominantly collective and anonymous form of oppositional behavior or dissent while "protest" emphasizes suggesting alternative approaches to solving societal problems. Thus, the rhetorical style most often visible in the language of political street stickers generally positions them as a means of expressing "resistance" rather than "protest."

45 Blanché, "Street Art and Related Terms," 34.

46 Reershemius, "Lamppost Networks," 625.

47 Endersby, "Tailgate Partisanship," 308; Bloch, “Mobile Discourse," 53.

48 Velikonja, Post-Socialist Political Graffiti, 19.

49 Ibid., 16.

50 Vigsø, "Extremist Stickers," 30.

51 Vigsø, "Extremist Stickers”; Reershemius, "Lamppost Networks.”

52 Stefano Bloch, "Challenging the Defence of Graffiti, in Defence of Graffiti" in The Routledge Handbook of Graffiti and Street Art, ed. Jeffrey Ian Ross (London and New York: Routledge, 2016), 440-451, 440.

53 Tiffany Renée Conklin, "Street Art, Ideology and Public Space” (PhD diss., Portland University, 2012), 157; Velikonja, Post-Socialist Political Graffiti, 20.

54 Awcock, "Stickin' It to the Man," 3.

55 Elizabeth Ritchie, "Yes after No: The Indyref Landscape, 2014-16," The Journal of British Identities 2, no.1 (2019): 1-30.

56 Velikonja, Post-Socialist Political Graffiti, 15 .

57 Ibid.

58 Axel Philipps, “Defacing Election Posters: A Form of Political Culture Jamming?” Popular Communication 13, no. 3 (2015): 183-201, 183, https://doi.org/10.1080/15405702.2014.974759. 


\section{Michael Cole}

Though opportunities to contest the statements presented on political stickers are usually lacking in the moment of initial interaction, those holding opposing views may later deface, adapt or cover stickers in such a way as to alter their original messages. Ritchie observed several examples of such "sticker wars" between the two opposing sides-conveniently known as "Yes" and "No"-in the 2014 Scottish Independence referendum. ${ }^{59}$ In some instances, the word "Yes" was handwritten over stickers displaying the word "No," while stickers containing "Yes" were covered with stickers that read "No" or "Naw." ${ }^{\circ 0}$ Further opportunities to respond to the messages political stickers display also increasingly exist in specialized online forums where users share images of stickers for discussion. ${ }^{61}$

This level of abstraction from the original spatio-temporal context in which they appear may have a considerable impact on how messages presented on stickers are subsequently interpreted. ${ }^{62}$ However, there is equally a growing tendency for street artists of all disciplines to produce works with an awareness that their online "afterlives" will be at least as significant, if not more so, in eliciting reactions from broader audiences than the original pieces. ${ }^{63}$ This is also true to an extent for political street stickers that, like those observed by Ritchie, are posted on road signs in remote locations so far from view as to be unreadable to passersby and seemingly "not intended to be read." 64

While this paper agrees that the spatial locations of political stickers are crucial in determining the broader contexts through which to examine their creators' intentions and their potential impact on broader societal discourses, it is temporal location that may provide greater academic insights. The uniqueness of stickers as a genre of political and social expression appears to lie predominantly in their ability to carry timely and relevant messages in response to current political and social developments and issues. Awcock, ${ }^{65}$ for instance, observed a large number of stickers referring to COVID-19 during the onset of the global pandemic in early 2020, which would presumably maintain meaning if observed outside their immediate spatial context but might become less relevant at a distance of weeks or months from their original temporal location.

This is not to suggest that political stickers, like other forms of street art, may not survive physically intact beyond the temporal expiry date of their message. Just as Velikonja observed that pro-Stalin graffiti created during the 1940s was still visible in Ljubljana almost 70 years after its creation, ${ }^{66}$ stickers may also remain in place long after the immediate issue to which they refer has seemingly passed into irrelevance. Ritchie's study suggests that both the physical durability of stickers and the enduring relevance of the messages they carry in the locations where they appear can facilitate their longevity. ${ }^{67}$ In the case of the Scottish Independence referendum, the continued presence of "Yes" campaign stickers in locations throughout Scotland alluded to the continued relevance of the issue and may have contributed to keeping the question of independence present in public consciousness.

Having outlined the key characteristics of political street stickers as a unique genre of socio-cultural expression, the next section presents an overview of the contextual

59 Ritchie, "Yes after No," 17.

60 Ibid, 17.

61 Reershemius, "Lamppost Networks," 640.

62 Susan Hansen and Flynn Danny, “'This Is Not a Banksy!': Street Art as Aesthetic Protest,” Continuum 29, no. 6 (2015): 898-912, 901, https://doi.org/10.1080/10304312.2015.1073685.

63 Katja Glaser, "The 'Place to Be for Street Art Nowadays is no Longer the Street, It's the Internet," SAUC-

Street Art \& Urban Creativity Scientific Journal 1, no. 2 (2015): 6-13, 7, https://doi.org/10.25765/sauc.v1i2.23.

64 Ritchie, "Yes after No," 21.

65 Awcock, "Stickin' It to the Man," 4.

66 Velikonja, Post-Socialist Political Graffiti, 68.

67 Ritchie, "Yes after No," 2. 
background against which this study was conducted: the 2020 Polish presidential election.

\section{The 2020 Polish Presidential Election}

In July 2020, incumbent Andrzej Duda was re-elected as President of Poland following a highly divisive electoral campaign that was regarded as a pivotal vote on Poland's future trajectory. ${ }^{68}$ Despite being backed by ruling right-wing populist party Law and Justice (Prawa i Sprawedliwosc, PiS), who hold considerable control over Polish public media, ${ }^{69}$ Duda achieved only a narrow victory following a secondround run-off against liberal Warsaw Mayor Rafał Trzaskowski.70 During the campaign, clear distinctions were drawn in public debate between the positions of the two leading candidates. These extended beyond traditional left-right divisions to emphasize their opposing stances on LGBT+ rights in Poland..$^{71}$ Whereas Duda described the LGBT+ community as an "ideology worse than communism" 72 from which Polish children needed protection, ${ }^{73}$ Trzaskowski voiced his support for same-sex marriage, advocated Warsaw as a welcoming place for LGBT+ people, and participated in the capital's 2019 Pride march. ${ }^{74}$

The emergence of LGBT+ rights issues as the nodal point of socio-political divisions around which the election was contested seems to epitomize the shift from the political to the metapolitical in Poland, whereby key battlegrounds no longer concern whose ideas are the best, but who has the right to have ideas at all.75 In part, the opposing discourses evident during the 2020 presidential election campaign result from Law and Justice's harnessing of pre-existing socially conservative sentiment among a range of groups in Poland ${ }^{76}$ to facilitate a cultural backlash against Western cultural norms, which are presented as existential threats to the Polish nation. ${ }^{77}$ For Law and Justice, the fundamental basis of Polish identity is ethno-religious ${ }^{78}$ and thus inescapably intertwined with Catholicism..$^{79}$ Articulations of national identity that differ from the hegemonic understandings provided and promoted by the Catholic Church are therefore frequently dismissed as symbolically incompatible with notions of "true" Polishness-and, by extension, treated as constituting an existential threat

68 Adam Easton, "Duda vs Trzaskowski: The Fight for Poland's Future," BBC News, July 10, 2020, https:// www.bbc.com/news/world-europe-53339992; Shaun Walker, "Duda Narrowly Re-Elected in Poland in Boost for Ruling Nationalists," The Guardian, July 13, 2020, https://www.theguardian.com/world/2020/jul/13/ incumbent-andrzej-duda-wins-polish-presidential-election-commission.

69 Yatsyk, "Biopolitical Conservatism in Europe and Beyond," 1.

70 Walker, "Duda Narrowly Re-Elected."

71 Theise, "LGBT Rights.”

72 James Shotter, “Poland's President Says 'LGBT Ideology' Worse than Communism," Financial Times, June 13, 2020, https://www.ft.com/content/f1689ob1-781f-4eda-98a7-a59e3fff8efb.

73 Shaun Walker, “Polish President Issues Pledge to Fight 'LGBT Ideology,” The Guardian, June 12, 2020, https://www.theguardian.com/world/2020/jun/12/polish-president-issues-campaign-pledge-to-fight-lgbtideology.

74 Vanessa Gera, "Mayor Marches in Pride Parade amid Poland's Anti-LGBT Campaign," CTV News, June 8, 2019, https://www.ctvnews.ca/world/mayor-marches-in-pride-parade-amid-poland-s-anti-lgbtcampaign-1.4458046; Theise, "LGBT Rights."

75 Stanley Bill and Ben Stanley, "Whose Poland Is It to Be? PiS and the Struggle between Monism and Pluralism," East European Politics 36, no. 3 (2020): 378-394, 383, https://doi.org/10.1080/21599165.2020.1 787161 .

76 Marta Kotwas and Jan Kubik, "Symbolic Thickening of Public Culture and the Rise of Right-Wing Populism in Poland," East European Politics and Societies and Cultures 33, no. 2 (2019): 435-471, 459, https://doi. org/10.1177/0888325419826691.

77 Bill and Stanley, "Whose Poland Is It to Be?," 387.

78 Kotwas and Kubik, "Symbolic Thickening of Public Culture," 439.

79 Anna Szwed and Katarzyna Zielińska, "A War on Gender? The Roman Catholic Church's Discourse on Gender in Poland" in Religion, Politics and Values in Poland: Continuity and Change Since 1989, ed. Sabrina

P. Ramet and Irena Borowik (New York: Palgrave MacMillan, 2017), 113-136, 131. 


\section{Michael Cole}

to the nation. ${ }^{80}$

At the same time, this narrowly defined understanding of identity as based on an "intensely nationalistic Pole-Catholic model," ${ }^{1}$ which permeates mainstream societal consciousness, facilitates the exclusion of alternative articulations, which are readily discredited as "nihilistic" 82 and diametrically opposed to the "sacred" set of characteristic "Polish" norms..$^{{ }^{3}}$ Cultural factors should not be understood as the sole cause of right-wing populist success in Poland without also taking into account their interaction with economic and political developments. ${ }^{84}$ However, the symbolic thickening of public culture ${ }^{85}$ with an emphasis on the synonymity of Polish identity and Catholicism, does provide an important point of contestation against which alternative discursive understandings of "Polishness" are unfavorably positioned.

This paper agrees with Bill and Stanley that the use of divisive populist tactics by Law and Justice and Andrzej Duda, the party's candidate in the 2020 presidential election, to appeal to as wide a range of voters as possible is perhaps as much tactical as it is ideological. ${ }^{86}$ The rhetorical foregrounding during the campaign of the supposed threat posed to the "very biological and cultural existence of the nation" by the LGBT+ community ${ }^{87}$ suggests a considered biopolitical feature of Law and Justice's agenda, an aspect that is beginning to receive greater attention in the literature..$^{88}$ Accordingly, the next section examines biopolitical theory to provide a suitable basis from which to explore the specific case of Poland during the 2020 presidential election campaign.

\section{Biopolitics and Biopower in Poland}

Biopolitics encapsulates the "processes of power and governance targeted at health, sanitation, birth rate and sexuality." ${ }^{89}$ Such processes position life itself as the object that political actors aim to affect in order to reach their desired goals. ${ }^{\circ 0}$ The concept emanates from Foucault, who articulated the related concept of biopower as "the set of mechanisms through which the basic biological features of the human species became the object of a political strategy, of a general strategy of Power." ${ }^{11}$ Thus, biopower does not simply refer to the physical or spatial control of "governable" aspects of the lives of ordinary citizens, but involves the "extension of state sovereignty into private lives." 92

Biopolitics has played a divisive role in Polish political debate since the fall of

8o Irena Borowik, "Religion in Poland Between Tradition and Modernity, or Religious Continuity and Change in Conditions of Transformation" in Religion, Politics and Values in Poland: Continuity and Change Since 1989, ed. Sabrina P. Ramet and Irena Borowik (New York: Palgrave MacMillan, 2017), 185-207, 195.

81 Kotwas and Kubik, "Symbolic Thickening of Public Culture," 458.

82 Katarzyna Leszczyńska, "The Roman Catholic Church in Poland vis-à- vis Europe and the Processes of European Integration. Three Pictures of Europe" in Religion, Politics and Values in Poland: Continuity and Change Since 1989, ed. Sabrina P. Ramet and Irena Borowik (New York: Palgrave MacMillan, 2017), 72.

83 Bill and Stanley, "Whose Poland Is It to Be?," 387.

84 Kotwas and Kubik, "Symbolic Thickening of Public Culture," 442.

85 Ibid., 443.

86 Bill and Stanley, "Whose Poland Is It to Be?," 389.

87 Ibid., 389.

88 Płotka, "Biopolitics, Ideology, and Citizenship"; Yatsyk, "Biopolitical Conservatism in Europe and Beyond."

89 James Gordon Finlayson, "Bare Life' and Politics in Agamben's Reading of Aristotle," The Review of Politics 72, no. 1 (2010): 97, https://doi.org/10.1017/S0034670509990982.

90 Thomas Lemke and Stéphane Baele, "An Interview with Thomas Lemke: Foucault Today. On the Theoretical Relevance of Foucauldian Concepts of 'Governmentality' and 'Biopolitics," Emulations 2, no. 4: 46-51, 48.

91 Michel Foucault, Security, Territory, Population: Lectures at the Collège de France 1977-1978 (New York: Picador, 2009), 1.

92 Andrey Makarychev and Sergey Medvedev, "Biopolitics and Power in Putin's Russia," Problems of PostCommunism 62, no. 1 (2015): 45-54, 45, https://doi.org/10.1080/10758216.2015.1002340. 
communism, most notably in relation to abortion rights, but also on issues surrounding organ donation and in vitro fertilization. ${ }^{93}$ For Płotka, biopolitical contention in Poland centers around the hegemonic "bioconservative" ideology promoted by ruling party Law and Justice, on one side, and the "bioliberal" views of opposition and non-hegemonic political actors, on the other. ${ }^{94}$ The 2020 judicial reforms in Poland, which further restricted women's access to abortions, provide a tangible recent example of the manifestation of Law and Justice's biopolitical agenda. ${ }^{95}$ The abortion reforms also highlight the influence of Catholicism in shaping this agenda, as they were justified on the grounds that unborn children have the right to live and are thus protected by the Polish constitution. ${ }^{96}$

The polarization Płotka highlights is not specific to biopolitical issues, but rather consistent with broader socio-political divisions in Polish society. ${ }^{97}$ Yet the continued prevalence of biopolitical issues in Polish politics since the end of communism ${ }^{98}$ suggests both an ideological facet to Law and Justice's conceptualizations of Polish national identity 99 and a considered strategic use of "biopolitical thinking" create and foreground narratives that resonate with their rural support base. ${ }^{101}$ To this end, Yatsyk proposes an understanding of Law and Justice's use of biopolitics as being, rather than purely ideological, a series of calculated approaches used to exert power over the population under the guise of ensuring national security. ${ }^{102}$ Makarychev and Yatsyk develop this concept of biopolitics beyond state desires to control populations, ${ }^{103}$ explaining the strategies used as tantamount to nationbuilding. The enactment of laws requiring conformation to strictly defined norms of sexual and reproductive behavior creates a conceptual dichotomy between "normal" citizens, who follow said laws and can therefore be considered members of society, and "abnormal" citizens, who are excluded by virtue of their non-compliance. ${ }^{104}$ The impact of Law and Justice's biopolitical conservatism on broader discourses in Polish society is difficult to assess. However, the regular appearance and acceptance in major cities, including Krakow, of anti-abortion protestors who display graphic images of aborted fetuses juxtaposed with pictures of healthy children dressed in patriotic Polish clothing ${ }^{105}$ provides one prevalent and highly visual example of its manifestation.

Of particular relevance for this study is the biopolitical thinking evident in narratives presented by Law and Justice and Andrzej Duda surrounding the supposed threat posed by the LGBT+ community to Polish national identity. ${ }^{106}$ Key aspects of this anti-LGBT+ discourse, which is also promoted by the Polish far right, portray the LGBT+ community as pedophiles and "Christianophobes" who aim to destroy the

93 Płotka, "Biopolitics, Ideology, and Citizenship," 139.

94 Ibid., 142.

95 Joanna Plucinska and Anna Wlodarczak-Semczuk, "Poland Puts into Effect New Restrictions on Abortion," Reuters, January 27, 2021, https://www.reuters.com/article/us-poland-abortion-idUSKBN29W1ZN.

96 “Poland Enforces Controversial Near-Total Abortion Ban,” BBC News, January 28, 2021, https://www.bbc. com/news/world-europe-55838210.

97 Kotwas and Kubik, "Symbolic Thickening of Public Culture," 461.

98 Płotka, "Biopolitics, Ideology, and Citizenship," 139.

99 Andrey Makarychev and Alexandra Yatsyk, "Biopolitics and National Identities: Between Liberalism and Totalization," Nationalities Papers 45, no. 1 (2017): 4, https://doi.org/10.1080/00905992.2016.1225705.

100 Yatsyk, "Biopolitical Conservatism in Europe and Beyond," 2.

101 Ibid., 4.

102 Ibid., 2.

103 Makarychev and Yatsyk, "Biopolitics and National Identities.”

104 Ibid., xiii.

105 Ben Koshchalka, "Kraków Council Votes to Ban Images of Aborted Foetuses in Public Space," Notes from Poland, November 22, 2020, https://notesfrompoland.com/2020/11/22/krakow-council-votes-to-ban-imagesof-aborted-foetuses-in-public-space/.

106 Marc Santora, "Poland Purges Its Supreme Court, and Protesters Take to the Streets," New York Times, July 3, 2018, https://www.nytimes.com/2018/o7/o3/world/europe/poland-supreme-court-protest.htm; Shotter, "Poland's President." 


\section{Michael Cole}

Catholic Church. ${ }^{107}$ The first of these accusations suggests parallels with approaches to biopolitical thinking in Russia, where references to the need to protect the country's children are used strategically to justify biopolitical policies that discriminate against sexual minorities. ${ }^{108}$ Additionally, presenting LGBT+ people as enemies of the church underlines their incompatibility with notions of "true" Polishness, which even in mainstream discourses is largely synonymous with Catholicism. ${ }^{109}$ This cultivates a logic of equivalence ${ }^{110}$ whereby the LGBT+ community is considered "foreign" 111 and an "ideology worse than communism" 112 from which children need to be protected. ${ }^{113}$

Perhaps the zenith of Law and Justice's strategic approach to biopolitics came in July 2019, when issues of the weekly newspaper Gazeta Polska were sold with stickers containing an image of a black cross superimposed over a rainbow and the slogan "LGBT-Free Zone."114 By providing a clear visual representation of Polish right-wing opposition to what the newspaper believed was an attack on traditional European values, the stickers contributed to over 100 Polish towns adopting "resolutions declaring themselves free of "LGBT ideology."” 115 Although predominantly symbolic, the resolutions elicited outrage from international observers, ${ }^{116}$ most notably the EU, which withheld funds from six such Polish towns ${ }^{117}$ and in March 2021 passed its own motion declaring the EU an "LGBTQI Freedom Zone." 118

However, as "deeply private issues of lifestyles and productive behaviour" 119 have become objects of urgent political action and discussion, the division encouraged in Polish society by the domination of right-wing and conservative political parties ${ }^{120}$ has equally provoked resistance from those on the opposite side of the dichotomy. Bielska, for instance, notes the socio-cultural impact of Poland's LGBT+ movement in introducing "ideas of civil unions, marriage equality and transgender rights into the mainstream discourse," as well as changing attitudes toward gay men and lesbians. ${ }^{121}$ Also crucial for this study is the formation of a collective identity among the Polish LGBT+ community, ${ }^{122}$ symbolized by both normative global and Poland-specific

107 Elzbieta Korolczuk, “The Fight against ‘Gender' and 'LGBT Ideology': New Developments in Poland," European Journal of Politics and Gender 3, no. 1 (2020): 165-167, 166, https://doi.org/10.13.32/2515 $10819 \mathrm{X} 15744244471843$.

108 Yatsyk, "Biopolitical Conservatism in Europe and Beyond," 4.

109 Piotr Żuk and Paweł Żuk, “"Murderers of the Unborn' and 'Sexual Degenerates': Analysis of the 'AntiGender' Discourse of the Catholic Church and the Nationalist Right in Poland," Critical Discourse Studies 17, no. 5 (2020): 566-588, https://doi.org/10.1080/17405904.2019.1676808.

110 David Howarth and Yannis Stavrakakis, "Introducing Discourse Theory and Political Analysis" in Discourse Theory and Political Analysis, ed. Aletta J. Norval and Yannis Stavrakakis (Manchester: Manchester University Press, 2000), 1-37, 11.

111 Żuk and Żuk, “'Murderers of the Unborn' and ‘Sexual Degenerates,” 571.

112 Shotter, "Poland's President."

113 Daniel Tilles, "Polish President Pledges to Defend Children from 'Foreign LGBT Ideology' Ahead of Election,” Notes From Poland, June 10, 2020, https://notesfrompoland.com/2020/06/10/polish-presidentpledges-to-defend-children-from-foreign-lgbt-ideology-ahead-of-election/.

114 Żuk, Pluciński, and Żuk, "The Dialectic of Neoliberal Exploitation,” 11.

115 Ibid., 11; Lucy Ash, “Inside Poland's 'LGBT-Free Zones,” BBC News, September 21, 2020, https://www.bbc. com/news/stories-54191344.

116 Ash, "Inside Poland's 'LGBT-Free Zones.”

117 Hugo Greenhalgh, "Poland Threatens to Challenge EU Funding Block in LGBT+ Row," Reuters, August 14, 2020, https://www.reuters.com/article/poland-lgbt-europe-idUSL8N2FG3IA.

118 European Parliament, "Parliament Declares the European Union an "LGBTIQ Freedom Zone," March 11, 2021, https://www.europarl.europa.eu/news/en/press-room/20210304IPR99219/parliament-declares-theeuropean-union-an-lgbtiq-freedom-zone.

119 Makarychev and Alexandra Yatsyk, "Biopolitics and National Identities,” 2.

120 Beata Bielska, “How Does the Movement Work? Above All, Inefficiently'. Political Outcomes of the Polish LGBT* Movement," Central Europe (2021): 1-13, 3, https://doi.org/10.1080/14790963.2021.1920134.

121 Ibid., 6.

122 Ibid., 11. 
LGBT+ symbols. ${ }^{123}$ It is this combination of symbols with slogans that this paper seeks to explore, with the aim of evaluating how political street stickers are used to present alternative conceptualizations of "Polishness" in resistance and response to the hegemonic discourse of Law and Justice. The next section details the methods used to identify, collect, and analyze the data used in this paper.

\section{Data and Methods of Analysis}

While systematic and comprehensive recording of political street stickers may provide insights into patterns of frequency and distribution, ${ }^{124}$ both the ephemeral nature of stickers and the changeable semiotic landscapes in which they appear suggest an ethnographic approach to data collection is most appropriate for this paper. ${ }^{125}$ Velikonja, for instance, highlights the challenges inherent in accurately counting and recording every example of street art or stickers in even a small city during a short space of time. ${ }^{126}$ Therefore, this paper does not claim to provide a fully comprehensive and systematic collection of all political street stickers posted in Krakow during the period in question.

However, to both ensure academic rigor in processing the data and identify salient patterns deserving of more detailed examination, ${ }^{127}$ this paper follows a twostep approach to content analysis. ${ }^{128}$ In the first step, each image was categorized manually according to the nature of the visual content it contained. Thus, from a corpus of 418 stickers photographed in the city between June and August 2020, 43 were identified as containing messages directly related to issues surrounding LGBT+ rights. Thirty-nine of these contained unique designs, with the remaining four being duplicates posted in different locations in Krakow. The appearance of these duplicate designs around the city is significant in demonstrating both the ratio of stickers related to LGBT+ rights in the corpus and the potential for increased visibility of the messages they carry. However, following Velikonja's approach to data collection, for the purposes of this paper, which analyzes the visual and linguistic content of stickers related to LGBT+ rights issues, duplicates are counted as one unit rather than several. ${ }^{129}$

The second stage consists of a qualitative examination of the linguistic and visual content of the stickers. Whereas frameworks for critical analysis of linguistic features are well established in the literature, systematic approaches to assessing the political significance of visual images present considerable methodological challenges. ${ }^{130}$ Even more than words, images must be interpreted to be understood, yet it is precisely this interpretative process that risks meanings being attributed to images that may more closely reflect the values and perspectives of interpreters than any qualities inherent in the images themselves. ${ }^{131}$ As a result, Bleiker calls for not only a mixed-methods approach to collecting and analyzing images, but also openness to combining apparently incompatible techniques. ${ }^{132}$ Accordingly, this study employs

123 Tomek Mossakowski, "The Polish LGBT Movement: Symbolic Conflict and Stigma” (Master>s thesis,

University of Tromsø, 2011).

124 Awcock, "Stickin' It to the Man," 7.

125 Reershemius, “Lamppost Networks,” 625; Jan Blommaert, Ethnography, Superdiversity and Linguistic Landscapes: Chronicles of Complexity (Bristol: Multilingual Matters, 2013).

126 Velikonja, Post-Socialist Political Graffiti, 36.

127 Catherine A. Lutz and Janet L. Collins, Reading National Geographic (Chicago: University of Chicago Press, 1993), 89 .

128 Gillian Rose, Visual Methodologies: An Introduction to Researching with Visual Materials (London: Sage, 2016), 85 .

129 Velikonja, Post-Socialist Political Graffiti, 68.

130 Roland Bleiker, "Pluralist Methods for Visual Global Politics,” Millennium 43, no. 3 (2015): 872-890, 872, https://doi.org/10.1177/0305829815583084.

131 Ibid., 875 .

132 Ibid., 873 . 


\section{Michael Cole}

a multi-modal discourse analysis incorporating visual content analysis and Critical Discourse Analysis (CDA) tools to assess the visual and linguistic features of the data.

Key to the analysis is a version of Velikonja's framework-which identifies four sites of meaning creation for the analysis of graffiti-that has been adapted to account for the unique features of political stickers. ${ }^{133}$ The first site of meaning is the site of context, which in the case of political works relates not only to spatio-temporal location, but also to the political environment in which they appear. Of particular relevance to the present study is meaning derived from "questioning the structures of power in a society, and sticking its nose into current social debates, dilemmas, and conflicts." ${ }^{34}$ Second is the site of the author, referring to the ideological intent of the creator of political street stickers, which also considers the relationships between individual works and broader repertoires of protest or political engagement of which they may be a component. ${ }^{135}$ Third is the site of the stickers themselves, which assesses the visual and linguistic features of works in terms of the messages they communicate independently of the broader socio-political context. ${ }^{136}$ Finally, the site of audiencing concerns reception of works by those who experience them in public spaces and the potential impact on their views surrounding issues presented. ${ }^{137}$

It is through a negotiation between these four sites that the overall meaning of the stickers can be fully understood, meaning an ideal approach considers each aspect of meaning creation equally. ${ }^{138}$ However, in practical terms, due to the lack of resources available, analyses of concrete case studies such as the present one begin with one site as the primary focus, with the other three drawn upon where the first proves insufficient. ${ }^{139}$ Therefore, the most logical starting point for this qualitative aspect of the study is the site of the stickers themselves, as it is through an understanding of their linguistic and visual content that the relationships between the different sites contributing to their overall meaning become evident. To do so, the concepts of denotation and connotation are utilized. Denotation refers simply to what is depicted in each of the stickers, whereas connotation aims to provide an account of the meanings these objects hold in terms of the ideas, values and wider discourses communicated..$^{140}$ Thus, what follows is an examination of the 39 unique sticker designs related to LGBT+ rights in Poland that considers the interplay between these factors as evidenced by the visual and linguistic features of the stickers themselves.

\section{Analysis}

Irrespective of their spatial or temporal context, each of the stickers examined in this study contained certain elements intrinsically denoting their connection to issues surrounding LGBT+ rights. Thirty-seven of the 39 stickers in the corpus featured variations on the theme of the rainbow, a symbol that has become synonymous with Pride and other LGBTQ+ social movements worldwide. ${ }^{141}$ These variations include images of actual rainbows, rainbow colors used as a background upon which text was placed, and the text itself being written in rainbow colors. Further examples incorporate images of rainbow-colored flags being held by various characters (see Figure 1). In Poland, the rainbow is increasingly seen as an "alien, invasive, and,

\footnotetext{
133 Velikonja, Post-Socialist Political Graffiti, 38.

134 Ibid., 39.

135 Ibid., 39.

136 Ibid, 40.

137 Ibid., 41.

138 Ibid., 41.

139 Ibid., 41.

140 Per Ledin and David Machin, Doing Visual Analysis: From Theory to Practice (London: Sage, 2018), 4748.

141 Nathalie Hauksson-Tresch, "The Rainbow Flag as Signal, Icon, Index and Symbol of Collective and Individual Gay Identity" in Flags, Color, and the Legal Narrative, ed. Anne Wagner and Sarah Marusek (Cham: Springer, 2021), 553-571.
} 
to those who consider homosexual acts a sin, even offensive symbol." ${ }^{142}$ Thus, in the broader socio-political context of Poland in 2020, outlined in detail above, the appearance of this rather simple combination of common colors becomes a visual manifestation of resistance to the hegemonic "bioconservative" ideology promoted by Law and Justice. ${ }^{143}$ That common colors can come to connote a form of antagonistic political expression simply through their appearance in public space elicits parallels with examples from Palestine, ${ }^{144}$ and more recently Belarus, in which even everyday items such as shopping bags and cakes symbolize resistance to the hegemonic discourse..$^{145}$

A second means of distinguishing between the stickers in the corpus relates to the inclusion of text and images. Of the 39 stickers analyzed, 22 contained only text, 14 combined text with images, one contained only images, and the remaining two were comprised simply of rainbow colors with no additional text or images. Thus, in total, 36 of the 39 stickers incorporated some form of written text, of which 18 were simply slogans and the remaining 18 a combination of slogans and names of identifiable organizations to which the messages can be connected. Having established these general trends in the data, a deeper analysis of the content of these texts and symbols provides further insights into the three remaining sites of analysis-content, author, and audience-each of which is now discussed in turn. ${ }^{146}$

Figure 1. Variations of the rainbow theme

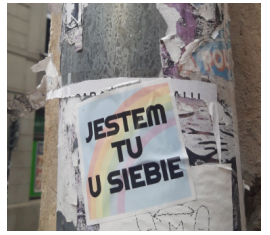

Picture 1: Rainbow image

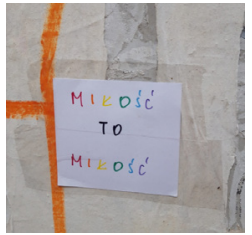

Picture 2: Rainbow-colored lettering

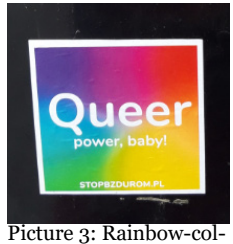

ored background

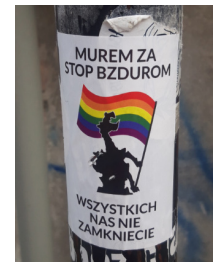

Picture 4: Rainbow flag held by dragon

A full account of the contextual factors influencing the meaning of the stickers analyzed in this study must consider both the time and location(s) in which they appeared.147 In terms of time, the broader socio-political context of discourses surrounding the 2020 Polish presidential election and in Poland more generally has already been outlined in some detail above. However, it is necessary to emphasize the importance of an awareness of this context to understanding the "full" meaning of the stickers. ${ }^{148}$ Unlike political bumper stickers in the US, which Endersby and Towle suggested were most common around the time of an election, ${ }^{149}$ none of the stickers analyzed in this study contained messages directly advocating for specific presidential candidates. However, their appearance in Krakow between June and August 2020, in light of the broader social discourse surrounding the two leading candidates' views on LGBT+ rights in Poland at that time, clearly connects them to

142 Ryszard Bobrowicz and Mattias Nowak, "Divided by the Rainbow: Culture War and Diffusion of Paleoconservative Values in Contemporary Poland," Religions 12, no. 3 (2021): 170, https://doi.org/10.3390/ rel12030170.

143 Płotka, "Biopolitics, Ideology, and Citizenship," 142.

144 Jackson Connor, "Why Watermelons Are a Symbol of Political Protest for Palestinians," Vice, October 2, 2015, https://www.vice.com/en/article/z4g3ya/why-watermelons-are-a-symbol-of-political-protest-forpalestinians.

145 Elizaveta Gaufman, "The Gendered Iconography of the Belarus Protest,” New Perspectives (2020): 1-10. 146 Velikonja, Post-Socialist Political Graffiti, 70.

147 Ibid., 39.

148 Ibid., 39.

149 Endersby, “Tailgate Partisanship,” 311. 


\section{Michael Cole}

the presidential election and connotes a desired outcome.

The linguistic content of the stickers also provides important insights related to the authors and potential target audiences of the messages presented. Consistent with Velikonja's work, none of the political street stickers analyzed in this study directly referenced identifiable individuals to whom the views they express could be attributed. ${ }^{150}$ However, of the 39 unique designs observed, 18 contained logos and/or addresses of web pages of the organizations responsible for producing the stickers: StopBzdurom (six stickers), Queerowy Maj (five stickers), KOD (Committee for the Defense of Democracy) (two stickers), Antifa (two stickers), Mowie Jak Jest (one sticker), kph.org.pl (Campaign against Homophobia) (one sticker), and St Pauli FC (one sticker). While an examination of their online content would allow for a deeper understanding of the aims and target audiences of each of these organizations, a certain amount can also be inferred about these two sites of meaning from the stickers themselves.

The first point to note in relation to language is the division between those stickers containing slogans written in Polish (27 stickers) and those featuring Englishlanguage texts (8 stickers). One of the latter group of stickers combined English with German-language slogans, while the final sticker in the corpus featured text exclusively in German. English-language slogans tend to be short (one to two words in length) and the messages affirmative rather than antagonistic. Slogans usedincluding "You're Fabulous," "Queer power, baby!" and "Love = Love = Love"-are simple and universally recognizable as associated with the LGBT+ community. The simplicity and universality of the English-language slogans on these stickers suggests a broad target audience for the messages they contain. In contrast, those with Polish-language texts are generally more complex, containing up to 15 words and predominantly antagonistic toward the hegemonic discourse promoted by Law and Justice regarding LGBT+ rights. Examples of this antagonism include "Patoprawico nie zesraj sie" (Right-wingers don't shit yourself) and "Wszystkich nas nie zamkniecie" (You won't lock us all up), with the latter slogan appearing on four separate sticker designs.

While these antagonistic phrases may be understandable to all Polish speakers irrespective of the time and locations they appear in, other stickers in the corpus contain intertextual references that rely more heavily on knowledge of the surrounding socio-political context for the overall meaning to be fully understood. The sticker in Figure 2, Picture 5, for instance, features the slogan "Strefa Wolna Od Pis" (PiSFree Zone), which is a direct response to the "Strefa Wolna Od LGBT" (LGBT-Free Zone) stickers circulated by Gazeta Polska in July 2019. ${ }^{151}$ Such "subvertising," which involves mimicking and co-opting official signs, slogans, and symbols to present opposing and conflicting viewpoints, is a common feature of street and protest art. ${ }^{152}$ Other examples of this in the corpus include "Strefa Wolna Od Nienawisci" (HateFree Zone) and "Krakow Wolny Od Nienawisci" (Krakow Free of Hate) (see Figure 2). This resistance to the hegemonic discourse through the subtle reconfiguration of a popular or well-known slogan resembles a campaign organized by anonymous campaigners in Porto, who posted stickers throughout the city containing the word "Morto," which means "dead" in Portuguese. ${ }^{153}$

150 Velikonja, Post-Socialist Political Graffiti, 19.

151 Żuk, Pluciński, and Żuk, "The Dialectic of Neoliberal Exploitation," 11.

152 Philipps, "Defacing Election Posters," 184.

153 Ana Duarte Melo and Sara Balonas, "Stickers on Politics. The Power of a Brand Is Its Weakness-A Case of Activism and Subvertising," in Organizational and Strategic Communication Research: Global Trends, ed. Isabel Ruiz-Mora, Gisela Gonçalves, and Ian Somerville (Covilha: Labcomp, 2019). 


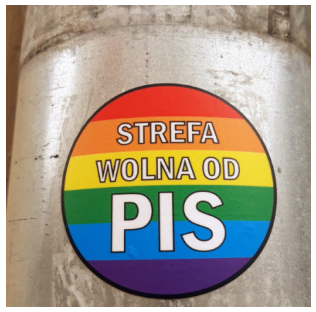

Picture 5: "Strefa Wolna od PiS" (PiS-Free Zone)

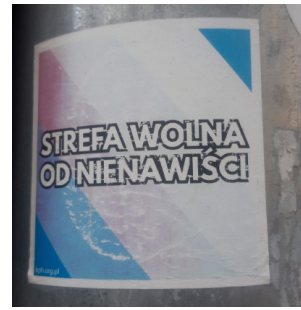

Picture 6: "Strefa Wolna Od Nienawisci" (Hate-Free Zone)

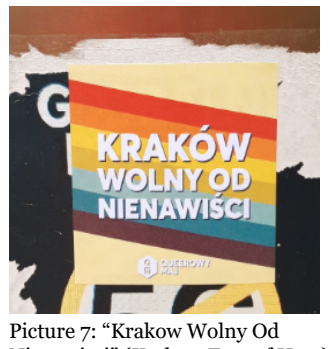

Nienawisci" (Krakow Free of Hate)

A second form of intertextuality evident in the linguistic content of the stickers is the use of direct quotations from well-known sources, connecting the struggle for LGBT+ rights to other contexts more familiar to Polish audiences. There were four examples of this among the stickers in the corpus. Two of the stickers featured quotes from the Bible, one displayed a quote from a Holocaust survivor, and a fourth contained a quote from a former U.S. president.

The first Bible quote-“Nie pozwól, by twoje stowo stato się ciatem" (Don’t let your word become flesh)-references an excerpt from John 1:14 (see Picture 8). The second-"Zaprawde powiadam wam: Co uczyniliscie jednemu z tych braci moich najmnieszych, mnie uczyniliscie" (Truly I tell you, whatever you did for one of the least of these brothers and sisters of mine, you did for me)-is from Matthew 25:40 (Picture 9 below). The centrality of Catholicism to notions of "true" Polish identity in the hegemonic discourse of Law and Justice suggests both excerpts would be familiar to Polish audiences. ${ }^{154}$ By superimposing these written citations over rainbowcolored backgrounds, their meanings are re-aligned to connect with contemporary debates in Poland surrounding LGBT+ rights. In this case, the aim appears to be to demonstrate the contradictions between the teachings of the Bible and the discursive exclusion of LGBT+ people from understandings of the Polish nation based on biopolitical reasoning. In Picture 9, the addition of an image resembling the outline of a murder victim with a wound to the chest provides further visual clarification of the potential outcomes that the authors predict will occur should anti-LGBT+ "words become flesh."

A third sticker presents a direct quote from Marian Turski, a Polish Holocaust survivor, journalist, and historian: "Auschwitz nie spadto z nieba" (Auschwitz didn't fall from the sky). Auschwitz, which is located less than 7okm from Krakow, is familiar worldwide as one of the largest concentration camps of World War II and a symbol of Nazi atrocities during the Holocaust. ${ }^{155}$ Its invocation here appears as a further warning to audiences that the biopolitical policies pursued by Law and Justice toward the Polish LGBT+ community resemble the discriminatory policies of the past that led to the horrors of Nazi concentration camps. The choice to incorporate the words of a respected member of Polish society who survived the Holocaust suggests a considered strategy to add credibility to the statement when drawing this parallel between past and present events.

The final sticker in the corpus containing a direct quote features the words "Kiedy niesprawiedliwość staje się prawem, opór staje się obowiazkiem" (When injustice becomes law, resistance becomes duty), which were originally spoken by former

154 Żuk and Żuk, “"Murderers of the Unborn' and 'Sexual Degenerates.”

155 Emily Schultheis, "In the Shadow of Auschwitz, a Town Seeks to Tell its Own Story," Institute of Current World Affairs, February 25, 2020, https://www.icwa.org/town-near-auschwitz-tells-its-story/. 


\section{Michael Cole}

U.S. President Thomas Jefferson. Not only has this phrase been used by civil rights movements around the world in campaigns against hegemonic powers, ${ }^{156}$ but in the Polish context it can also be interpreted as a form of ironic wordplay on the name of ruling party Law and Justice (Prawa i Sprawiedliwość), which here becomes "injustice" (niesprawiedliwość). In the case of all four stickers containing direct quotations, it is only with an awareness of relevant socio-political contextual factors that the full meaning can be deciphered.

Figure 3. Stickers containing direct quotations

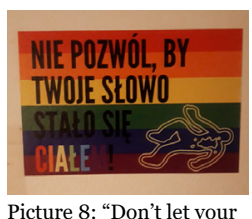
word become flesh"

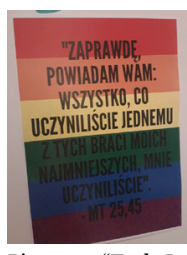

Picture 9: “Truly I tell you, whatever you did for one of the least of these brothers and sisters of mine, you did for me"

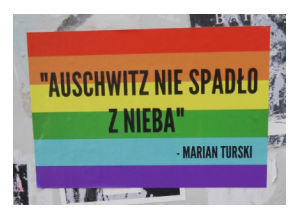

Picture 10: “Auschwitz didn't fall from the sky - Marian Turski”

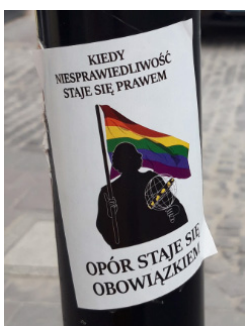

Picture 11: "When injustice becomes law, resistance becomes duty"

In addition to the linguistic content of the stickers, knowledge of the Polish context in which the stickers were created, posted, and observed is necessary to facilitate interpretation of the images and symbols they contain, which also contribute to understanding their full meaning. Fifteen of the 39 unique sticker designs analyzed contain images, with several featuring multiple components. The most common type of image featured on stickers in the corpus were black silhouettes or outlines of figures on white backgrounds, holding rainbow-colored flags and a range of other objects (see Figure 3 below). As mentioned above, the presence of the rainbow colors provides a visual connection to issues related to LGBT+ rights, while the slogans accompanying the images present information about the organization responsible for producing the stickers and the specific messages they wish to convey.

A further layer of meaning can be deduced through an awareness of the particular symbols used in these stickers, which are all based on images of statues located in either Warsaw or Krakow (see Figure 4 below). Picture 12, for instance, contains an outline of "Syrenka," a mermaid-like warrior figure who appears on Warsaw's coat of arms and is an instantly recognizable symbol of the city. Other stickers portray the likenesses of Polish-born mathematician and astronomer Nicolaus Copernicus (Picture 13), the statue of Jesus Christ located in front of Warsaw's Holy Cross church (Picture 14), and the Krakow dragon, which according to local legend lived in a cave beneath the city's royal "Wawel" castle (Picture 15). In each of the stickers, the statue represented is holding a rainbow-colored flag, creating the impression that these important national, local, and religious icons support the campaign for increased LGBT+ rights and by extension represent "bioliberal" anti-hegemonic views.

156 Paul Chatterton, “Give Up Activism' and Change the World in Unknown Ways: Or, Learning to Walk with Others on Uncommon Ground," Antipode 38, no. 2 (2006): 259-281, https://doi.org/10.1111/j.14678330.2006.00579.x. 


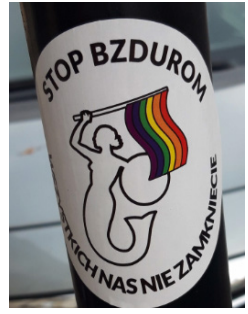

Picture 12: Syrenka, symbol of Warsaw

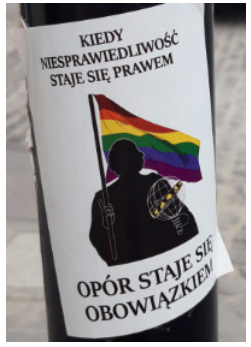

Picture 13: Statue of Nicolas Copernicus, Warsaw

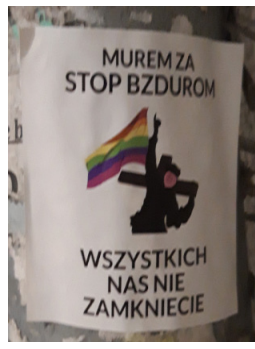

Picture 14: Stop Bzdurom Protestor and Statue of Christ, Warsaw

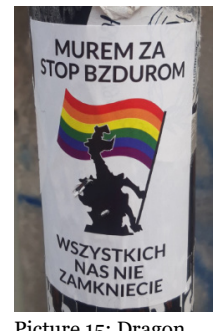

Picture 15: Dragon Statue, Krakow

In Poland, as elsewhere, symbols are important visual manifestations of national and local identity, ${ }^{157}$ with the figures represented in these stickers presumably chosen for that reason. Combining images of these important icons with the rainbow-colored flag is another form of subversion, adding to the antagonistic sentiment seen in many of the slogans. It also suggests an alternative understanding of Polish identity whereby being a national, local, or religious icon and supporting LGBT+ rights are not considered mutually exclusive. These stickers were produced by Stop Bzdurom (Stop Nonsense / Stop Bullshit), a Warsaw-based queer anarchist activist collective. A July 2020 post on the collective's Instagram page shows photographs of some of the same statues represented in these stickers adorned with rainbow flags, demonstrating that they are in fact visual representations of performative acts of resistance the group had previously undertaken in Warsaw. ${ }^{15^{8}}$ The text accompanying the images, while predominantly antagonistic, concludes with the statement "To miasto jest nas wszystkich" (This city is all of us). This at least partly supports the interpretation that the political agenda expressed in these stickers reflects aims for a more inclusive form of "Polishness" that incorporates LGBT+ people into conceptualizations of the Polish nation rather than accepting hegemonic discourses of exclusion based on biopolitical grounds.

\section{Conclusions}

This paper first identified political street stickers as a unique genre of socio-political expression that deserves far greater attention in the literature. As one of the most prominent forms of street art ${ }^{159}$ and a feature of contemporary street protests, ${ }^{160}$ street stickers offer a valuable glimpse of counter-discourses circulating in societies as well as efforts to consolidate tribal identities.

Having provided a definition of political street stickers that differentiates the genre from similar and related forms of political and social expression, this paper analyzed their appearance in response to the biopolitical agenda of the Polish government and its preferred candidate in the 2020 presidential election. A corpus of 39 unique stickers containing messages related to LGBT+ rights was analyzed using Velikonja's framework of four key sites that combine to create overall meaning: site of context, site of the author, site of the stickers themselves, and site of the audience.

The site of context was a significant contributor to the overall meaning of the stickers, as they were all photographed in Krakow, Poland, around the highly polarizing

157 Bobrowicz and Nowak, "Divided by the Rainbow," 5 .

158 Stop Bzdurem (@stopbzdurem), Instagram post, July 29, 2020, https://www.instagram.com/p/ CDOEI7bHfaf/.

159 Velikonja, Post-Socialist Political Graffiti, 143.

160 Awcock, "Stickin' It to the Man," 2. 


\section{Michael Cole}

2020 presidential election. The site of the author, while primarily deduced from the researcher's interpretations, appears to be one of resistance to the hegemonic discourse in Poland, which articulates the LGBT+ community as external to the nation on biopolitical grounds. In one sense, the images and language used in the stickers connect the Polish LGBT+ community to broader understandings of Polish identity through the co-option of familiar and important national symbols. The use of slogans containing intertextual references to aspects of the hegemonic discourse suggests some stickers were produced as a way of directly countering antagonistic discursive aggression aimed at the LGBT+ community by leading political actors in Poland.

The site of stickers themselves provides the richest source of data for visual discourse analysis, even in a relatively small number of images. Common features that connect the Polish LGBT+ community to those in other contexts include the use of the rainbow colors, which featured on almost all the images analyzed in this study. While this paper focused less on the site of audiencing, some preliminary conclusions can be drawn. The combination of Polish- and English-language content visible on the stickers, for instance, suggests at least two separate audiences, with messages tailored accordingly. Polish-language slogans directly reference elements of the national discourse related to the LGBT+ community and are generally antagonistic in nature. English-language slogans tend to be more positive in tone, invoking internationally recognizable tropes that celebrate the LGBT+ community.

This paper is one of very few early attempts to gain insight into the medium of political street stickers as a means of socio-political expression. It suggests several further avenues of investigation that may contribute to our understanding of issues related to the production and reception of political stickers themselves, as well as the broader ecosystems of protest and socio-cultural expression of which stickers are a part.

Causality between images and political change is rarely easy to establish, ${ }^{161}$ and as with related mediums such as political bumper stickers, it is unlikely that political street stickers in isolation "would cause world peace, produce a religious conversion, or inspire a partisan realignment." 162 Nevertheless, those who produce and post political street stickers surely believe that doing so is a meaningful and productive activity that contributes to encouraging political change. Therefore, another fruitful area of research involves engaging with those creating political street stickers to broaden our knowledge of the decisions made regarding stickers' linguistic and visual content, as well as the motivations for producing them and desired outcomes.

While the multimodal discourse analysis of stickers related to LGBT+ rights in Poland in this paper provides important insights into the visual symbols and patterns they contain, it is unable to account for stickers' impact on viewers or position within broader societal discourses. ${ }^{163}$ Thus, future research assessing audience responses to sticker content both "on the street" and in their digital "afterlives" in online forums will be crucial to improving our understanding of the success, or lack of, that stickers' visual and linguistic messages enjoy in convincing audiences to support particular political causes. 